\title{
Records of kogiid whales in Namibia, including the first record of the dwarf sperm whale (Kogia sima)-CORRIGENDUM
}

\author{
S.H. ELWEN, T. GRIDLEY, J.-P. ROUX, P.B. BEST AND M.J. SMALE
}

doi: http://dx.doi.org/10.1017/S1755267213000213. Vol. 6; e45; 2013 Published by the Marine Biological Association of the United Kingdom.

Within the Elwen et al. (2013) paper describing records of kogiid whales in Namibia, the following errors need to be highlighted:

MATERIALSANDMETHDDS:

Page 3, column 2, paragraph 2: Correct method to identify the two Kogia species from relative position of the dorsal fin from snout is: K. sima-anterior insertion of dorsal fin is $<50 \%$ of body length from snout; in K. breviceps it is $>50 \%$.

Page 3, column 2, paragraph 4: Sexual maturity of specimen KBo1 was additionally determined from body length after Best (2007).

Page 3, column 2, last paragraph: Sepiidae were the most numerous prey taxon (not species) taken by KSo1. Additionally, correct spelling of species name in family Ommastrephidae is Ommastrephes bartramii.

In Table 1, multiple species names were spelled incorrectly.

veranyi should be: veranii

bartrami should be: bartramii

Hystioteuethis should be: Histioteuthis

Brachiotuethidae should be: Brachioteuthidae (Family)

Onychoteurthidae should be: Onychoteuthidae (Family)

Lycotuthis should be: Lycoteuthis

spp. should be: sp.

juv? and juvs should be: juvenile

In Table 2, the asterisk on records 10 and 12 is not explained and should have the following text below table: Skull supposed to have been collected but whereabouts unknown.

Page 5, column 2, last paragraph: extra 'and' in the sentence should be disregarded and sentence should read: 'These patterns were supported by the lower density and smaller size of the prey in the stomach of KSo1 in this study'.

In the reference list, it must be noted that Best (2007) should be corrected to:

Best P.B. (2007) Whales and dolphins of the southern African subregion. Cape Town: Cambridge University Press.

\section{REFERENCES}

Best P.B. (2007) Whales and dolphins of the southern African subregion. Cape Town: Cambridge University Press.

and

Elwen S.H., Gridley T., Roux J.-P., Best P.B. and Smale M.J. (2013) Records of kogiid whales in Namibia, including the first record of the dwarf sperm whale (Kogia sima). Marine Biodiversity Records 6, e45, 8 pp. doi: http://dx.doi.org/10.1017/S1755267213000213. 